\title{
Hubungan antara Leptin dengan Demam Berdarah Dengue
}

\author{
James Widjaja, Max F.J. Mantik, Novie H. Rampengan \\ Bagian Ilmu Kesehatan Anak, Fakultas Kedokteran Universitas Sam Ratulangi/RSU Prof. Dr. R.D. \\ Kandou, Manado
}

Latar belakang. Patogenesis demam berdarah dengue (DBD) sampai saat ini masih belum jelas. Status gizi merupakan faktor risiko terjadinya perburukan pada DBD. Leptin, suatu protein hormon yang dihasilkan oleh sel adiposit diduga berperan dalam perburukan perjalanan penyakit DBD.

Tujuan. Mencari hubungan antara leptin dengan demam berdarah dengue pada anak.

Metode. Penelitian dilakukan secara analitik observasional dengan pendekatan potong lintang. Pasien didiagnosis DBD berdasarkan kriteria WHO dan dikonfirmasi dengan pemeriksaan serologis NS1 dengue IgG dan IgM atau anti dengue rapid test. Data berupa kadar hematokrit, jumlah trombosit, jumlah lekosit, kadar hemoglobin dan kadar leptin dikumpulkan selama penelitian. Analisis statistik menggunakan analisis deskriptif dan regresi logistik.

Hasil. Didapatkan tiga puluh delapan anak, 19 (50\%) lelaki dan 19 (50\%) perempuan. Duapuluh tujuh anak $(71,1 \%)$ didiagnosis DBD tanpa syok dan 11 anak $(28,9 \%)$ DBD dengan syok. Rerata kadar hemoglobin anak dengan DBD 13,23 (SB 1,78) g/dL (95\% IK 12,64-13,81), rerata kadar hematokrit 39,78 (SB 6,16)\% (95\% IK 37,75-41,80), rerata jumlah leukosit 5.366 (SB 2,410)/ $\mathrm{mm}^{3}$ (95\% IK 4,574-6,158), rerata jumlah trombosit 79,342 (SB 47,911)/ $\mathrm{mm}^{3}$ (95\% IK 63,594-95,090), rerata kadar plasma leptin anak yang menderita DBD 2417,88 (SB 7092,44) pg/mL (95\% IK 86,66 - 4749,11). Terdapat hubungan positif yang bermakna antara kadar leptin plasma darah dengan peluang terjadinya syok pada DBD anak $(\mathrm{p}=0,042)$.

Kesimpulan. Semakin tinggi kadar leptin, semakin besar peluang untuk terjadinya syok pada DBD.

Sari Pediatri 2013;15(4):254-8.

Kata kunci: leptin, demam berdarah dengue, anak

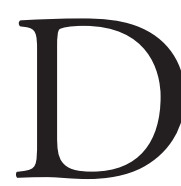

engue merupakan suatu penyakit infeksi virus yang menyebabkan masalah kesehatan serius di seluruh dunia. ${ }^{1,2}$ Terdapat banyak faktor dapat menerangkan patogenesis

\footnotetext{
Alamat korespondensi:

Dr. James Widjaja, Sp.A. Departemen Ilmu Kesehatan Anak. Fakultas Kedokteran Universitas Sam Ratulangi - RSU. Prof. Dr. R.D. Kandou, Manado Jl. Raya Tanawangko, Manado 95115. P.O. Box 66 ; Telp. (0431) 821652 ; Fax. (0431) 859091. E-mail : jamesw97@yahoo.com
}

DBD di antaranya adalah tropisme dari virus dengue, virulensi virus, aktivasi komplemen, autoimunitas sementara, faktor genetik dari pejamu, antibody-dependent enhancement (ADE), respon reaksi silang dari sel-T dan soluble factors yang berperan. Apapun mekanismenya, target kerusakannya adalah pada endotel vaskular yang menyebabkan peningkatan permeabilitas pembuluh darah dan aktivasi koagulasi. ${ }^{3-5}$

Leptin, suatu hormon protein diproduksi oleh sel adiposit telah lama diketahui mengatur metabolisme 
energi homeostasis, neuroendokrin, dan berbagai fungsi fisiologik lainnya. ${ }^{6,7}$ Leptin juga dikenal sebagai cytokine-like hormon dengan efek pleiotropik dalam modulasi respon imun dengan mengaktivasi sel monosit, dendritik dan makrofag serta menstimulasi sel tersebut memproduksi sitokin tipe Th $1 .{ }^{8,9}$

Status gizi dilaporkan mempunyai hubungan dengan peningkatan risiko timbulnya syok pada DBD. ${ }^{10}$ Pichainarong $\mathrm{dkk}^{11}$ menyatakan bahwa obesitas merupakan suatu faktor risiko komplikasi berat pada infeksi dengue. Peningkatan leptin pada anak dengan IMT yang tinggi diperkirakan akan memperberat penyakit DBD. Hal ini juga didasarkan atas pengalaman empiris bahwa anak dengan gizi lebih menunjukkan kecenderungan perburukan DBD.

\section{Metode}

Penelitian potong lintang pada semua kasus DBD, dilakukan di Bagian Ilmu Kesehatan Anak (BIKA)/ Irina E BLU. RSUP. Prof. Dr. R.D. Kandou, bangsal anak Rumah Sakit Umum (RSU) Pancaran Kasih, dan bangsal anak RSU Tingkat III Robert Wolter Monginsidi, mulai bulan Juli 2011 sampai dengan Desember 2011 dengan diagnosis DBD. Diagnosis DBD ditegakkan berdasarkan kriteria WHO 1997 dan dikonfirmasi dengan pemeriksaan NS1 dengue atau rapid test antidengue IgG dan IgM. Kriteria diagnosis DBD/SSD didasarkan pada kriteria klinis dan laboratoris dari WHO $1997 .{ }^{12}$ Kriteria inklusi adalah usia pasien 1-13 tahun, semua pasien yang di diagnosis sebagai DBD berdasarkan kriteria WHO 1997 dan dikonfirmasi dengan pemeriksaan serologis dan orang tua menyetujui ikut serta dengan bersedia mengisi formulir penelitian. Pengukuran leptin akan dilakukan apabila sampel telah memenuhi kriteria inklusi. Leptin diukur menggunakan human leptin immunoassay kit (Quantikine $\left.{ }^{\circledR}\right)$ yang diproduksi oleh R \& D systems Inc. 614 McKinley Place. N. E. Minneapolis, MN 55413 USA dan dinyatakan dalam satuan pikogram (pg).

Analisis data menggunakan analisis deskriptif dan analisis regresi logistik yang diolah dengan menggunakan program SPSS versi 20 untuk mengetahui data karakteristik anak, data laboratorium, dan untuk mengetahui hubungan antara kadar leptin yang tinggi dengan penyakit DBD pada anak.

\section{Hasil}

Didapatkan 38 pasien DBD tanpa syok dan dengan syok yang memenuhi kriteria inklusi penelitian, terdiri dari 19 (50\%) laki-laki dan 19 (50\%) perempuan. Jumlah anak laki-laki pada kelompok DBD tanpa syok $15(55,6 \%)$ dan DBD dengan syok $4(36,4 \%)$. Jumlah anak perempuan pada kelompok DBD tanpa syok $12(44,4 \%)$ dan DBD dengan syok 7 (63,6\%). Rerata usia pada kelompok DBD tanpa syok 6,19 (SB

Tabel 1. Karakteristik hasil laboratorium penelitian

\begin{tabular}{|c|c|c|c|}
\hline & DBD (total) & DBD tanpa syok & DBD dengan syok \\
\hline \multicolumn{4}{|l|}{ Hemoglobin (gr/dL) } \\
\hline Rerata (SB) & $13,23(1,78)$ & $12,71(1,16)$ & $14,49(2,38)$ \\
\hline Median $(95 \%$ IK) & $13,30(12,64-13,81)$ & $13,00(12,25-13,17)$ & $14,30(12,89-16,09)$ \\
\hline \multicolumn{4}{|l|}{ Hematokrit (\%) } \\
\hline Rerata (SB) & $39,78(6,16)$ & $37,57(4,22)$ & $45,20(6,97)$ \\
\hline Median $(95 \% \mathrm{IK})$ & $39,78(37,37-41,80)$ & $37,70(35,89-39,24)$ & $44,00(40,52-49,88)$ \\
\hline \multicolumn{4}{|l|}{ Leukosit $\left(/ \mathrm{mm}^{3}\right)$} \\
\hline Rerata (SB) & $5,366(2,410)$ & $4,778(1,764)$ & $6,809(3,190)$ \\
\hline Median (95\% IK) & $4,980(4,574-6,158)$ & $4,700(4,080-5,476)$ & $6,200(4,666-8,953)$ \\
\hline \multicolumn{4}{|l|}{ Trombosit $\left(/ \mathrm{mm}^{3}\right)$} \\
\hline Rerata (SB) & $73,342(47,911)$ & $90,482(46,426)$ & $52,000(41,617)$ \\
\hline Median (95\% IK) & $79,342(63,594-95,096)$ & $81,000(72,116-108,847)$ & $44,000(24,041-79,959$ \\
\hline \multicolumn{4}{|l|}{ Leptin $(\mathrm{pg} / \mathrm{ml})$} \\
\hline Rerata (SB) & $2417,88(7092,44)$ & $646,78(416,11)$ & $6765,14(12506,49)$ \\
\hline Median (95\% IK) & $554,30(86,66-4749,11)$ & $529,00(482,18-811,39)$ & $2264,00(1636,84-15167,11)$ \\
\hline
\end{tabular}


Tabel 2. Analisis hubungan Leptin dengan DBD

\begin{tabular}{lcc}
\hline Model & Koefisien regresi & $\mathrm{p}$ \\
\hline Konstanta & $-2,335$ & 0,001 \\
Leptin & 0,001 & 0,042 \\
\hline
\end{tabular}

$3,013)$ tahun $(95 \%$ IK 4,99-7,38), sedangkan dengan syok 6,82 (SB 3,25) tahun (95\% IK 4,63-9,00). Secara umum, rerata usia anak dengan DBD adalah 6,37 (SB 3,053) tahun (95\% IK 5,36 - 7,37).

Karakteristik hasil laboratorium dan berdasarkan kelompok tertera pada Tabel 1. Rerata kadar leptin anak dengan DBD adalah 2417,89 (SD 7092,44) pg/ $\mathrm{mL}$ (95\% IK 86,66-4749,11), sedangkan berdasarkan kelompok, rerata kadar leptin DBD tanpa syok adalah 646,78 (SD 416,11) pg/mL (95\% IK 482,18-811,39) dan DBD dengan syok adalah 6765,14 (SD 12506,49) pg/mL (95\% IK 1636,84-15167,11).

Berdasarkan hasil analisis regresi logistik terhadap hubungan antara kadar leptin dengan DBD (Tabel 2), didapatkan bahwa terdapat hubungan yang bermakna antara kadar plasma leptin dengan terjadinya syok pada DBD. Koefisien regresi bernilai positif, yaitu menandakan bahwa hubungan yang dimiliki berupa hubungan yang positif. Hasil tersebut menyatakan bahwa semakin tinggi kadar leptin, semakin besar peluang terjadinya syok pada DBD. Besaran peluang terjadinya syok pada DBD apabila kadar leptin diketahui tertera pada Gambar 1.

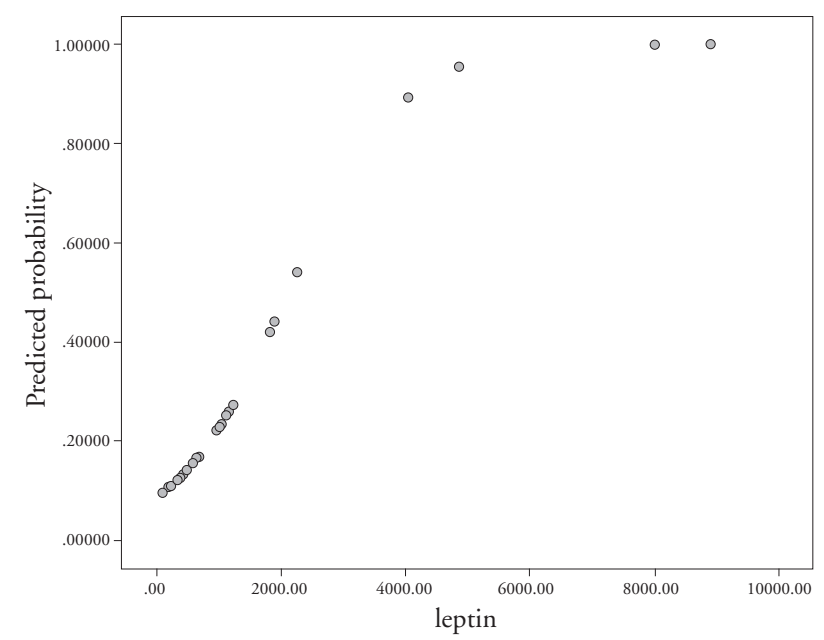

Gambar 1. Grafik peluang terjadi syok pada berbagai kadar leptin

\section{Pembahasan}

Demam berdarah dengue bermanifestasi klinis berupa suatu sindrom ditandai dengan kebocoran plasma yang bersifat mendadak dan sementara. Proses kebocoran plasma pada DBD terjadi, meski reaksi peradangan pada jaringan tidak terlalu hebat. Hal tersebut mengindikasikan bahwa adanya perubahan sementara dari faktor-faktor yang mengatur permeabilitas vaskular mungkin merupakan mekanisme penyebab terjadinya kebocoran plasma pada penyakit ini. ${ }^{14}$

Sitokin adalah protein terlarut yang berfungsi dalam respon imun alami maupun adaptif, protein ini banyak terekspresi pada keadaan inflamasi atau infeksi. Infeksi virus dengue pada sel endotel menyebabkan produksi kemokin, aktivasi komplemen, dan apoptosis. ${ }^{15}$ Virus dengue bereplikasi di dalam makrofag untuk memproduksi buman cytotoxic factor (hCF) yang menginduksi makrofag untuk memproduksi radikal bebas, nitrit, reaktif oksigen, dan peroksinitrit. Radikal bebas meregulasi produksi sitokin proinflamasi IFN- $\gamma$, TNF- $\alpha$, IL-8, dan hidrogen peroksidase dalam makrofag. Permeabilitas vaskular meningkat akibat efek dari histamin, radikal bebas, sitokin proinflamatori, dan produksi dari jalur komplemen. ${ }^{16}$ Basu dan Chaturvedimen ${ }^{5}$ mengemukakan bahwa peningkatan permeabilitas vaskular yang tanpa disertai oleh kelainan morfologi pada DBD disebabkan oleh karena adanya "cytokine tsunami" yang diakibatkan oleh berbagai patomekanisme.

Salah satu sitokin yang berperan dalam terjadinya DBD adalah TNF- $\alpha$. Efek biologi TNF- $\alpha$ adalah meningkatkan ekspresi molekul adhesi pada permukaan endotel pembuluh darah, yaitu intercelular adhesion molecule-1 (ICAM-I), vascular cell adhesion molecule-1 (VCAM-I) selektin dan integrin ligand dan pada permukaan leukosit yaitu selektin ligand dan integrin. Ekspresi molekul adhesi tersebut akan menyebabkan peningkatan permeabilitas pembuluh darah dan migrasi. ${ }^{16}$

Ganda ${ }^{17}$ menyatakan bahwa kadar TNF- $\alpha$ serum ditemukan lebih tinggi pada kelompok DBD yang mengalami syok, sedangkan Chakravarti $\mathrm{dkk}^{18}$ menyebutkan bahwa produksi TNF- $\alpha$ yang berlebihan selama infeksi sekunder mempunyai peran dalam imunopatogenesis DBD.

Kami mendapatkan adanya hubungan antara kadar leptin plasma darah dengan peluang terjadinya syok pada DBD anak. Hasil tersebut menyatakan bahwa 
semakin tinggi kadar leptin, semakin besar peluang untuk terjadinya syok pada DBD. Syok merupakan manifestasi klinis yang menandakan adanya suatu kebocoran plasma yang berat pada DBD. Hal tersebut menunjukkan bahwa leptin berhubungan dengan derajat kebocoran plasma yang terjadi; semakin tinggi kadar leptin semakin berat derajat kebocoran plasma yang terjadi sehingga berpotensi untuk menyebabkan syok.

Penelitian kami merupakan yang pertama kali dilakukan untuk melihat hubungan antara leptin dengan keparahan pada DBD. Faktor yang memengaruhi atau berperan dalam patomekanisme bagaimana leptin dapat memperburuk DBD masih belum jelas. Peneliti memperkirakan adanya perantaraan dari TNF- $\alpha$ pada kadar leptin yang tinggi sehingga terjadi perburukan DBD. Leptin dapat memodulasi sistem imun sehingga dapat mengaktivasi dan stimulasi monosit, sel dendritik dan makrofag untuk memproduksi sitokin Th1. Aktivasi dan stimulasi monosit dan makrofag akan menghasilkan pembentukan IL-1, IL-6 dan TNF- $\alpha .{ }^{8}$ Seperti yang dilaporkan oleh Gabay dkk ${ }^{19}$ bahwa leptin dapat merangsang sekresi TNF- $\alpha$, IL-6 dan IL-12. Dilain pihak, akibat infeksi virus dengue, monosit/makrofag akan bereaksi dengan mengeluarkan sitokin salah satunya adalah TNF- $\alpha$. Finck $\mathrm{dkk}^{20}$ memperlihatkan bahwa sekresi TNF- $\alpha$ dibutuhkan untuk meningkatkan leptin plasma yang disebabkan oleh stimulasi dari LPS. Dalam studi ini TNF- $\alpha$ akan menginduksi langsung sel-sel adiposit untuk memproduksi leptin. Akibatnya akan terjadi suatu "lingkaran" saat leptin akan menghasilkan TNF- $\alpha$ dan TNF- $\alpha$ juga akan merangsang lemak putih untuk mengeluarkan leptin secara terus menerus sehingga akan mengakibatkan terjadinya suatu "badai sitokin" yang merupakan salah satu teori terjadinya DBD.

Penelitian kami memberikan pemahaman yang baru tentang patogenesis dari DBD/SSD yang hingga saat ini masih belum dapat dijelaskan secara keseluruhan. Keterbatasan penelitian kami adalah sifat dari penelitian potong lintang, sehingga pemeriksaan kadar leptin hanya dilakukan satu kali yaitu pada saat pasien masuk ke rumah sakit. Penelitian tentang hubungan leptin dengan DBD yang bersifat prospektif kohort perlu dlakukan. Kami hanya mencari hubungan antara leptin dengan keparahan DBD sehingga perlu dilakukan penelitian lanjutan untuk mencari tahu secara pasti bagaimana patogenesis leptin dapat memperparah DBD dan faktor-faktor yang memengaruhinya. Kami juga tidak melihat status gizi atau indeks massa tubuh yang berhubungan dengan peningkatan leptin.

\section{Kesimpulan}

Terdapat hubungan positif, semakin tinggi kadar plasma leptin semakin besar pula peluang terjadinya syok pada DBD.

\section{Daftar pustaka}

1. WHO. Dengue: guidelines for diagnosis, treatment, prevention and control. Geneva: WHO Press; 2009.h.316.

2. Halstead BS. Dengue. Lancet 2007;370:1644-52.

3. Rampengan TH. Demam berdarah dengue. Dalam: Rarnpengan TH, Laurents IR, penyunting. Penyakit infeksi tropik pada anak. Edisi 2. Jakarta: EGC; 2007.h.135-55.

4. Sosothikul D, Seksran P, Pongsewalak S, Thisyakorn U, Lusher J. Activation of endothelial cells, coagulation and fibrinolysis in children with Dengue virus infection. Thromb Haemost 2007;97:627-34.

5. Basu A, Chaturvedi CU. Vascular endothelium: The battlefield of dengue viruses. FEMS Immunol Med Microbiol 2008;53:287-99.

6. Hassink SG, Shelow DV, de Lancey E, Opentanova I, Considine RV, Caro JF. Serum leptin in children with obesity: Relationship to gender and development. Pediatrics 1996;98:201-3.

7. Aygunn A D, Gungor S, Ustundag B, Gurgoze M K, Sen Y. Proinflammatory cytokines and leptin are increased in serum of prepubertal obese children. Med of inflama 2005;3:180-3.

8. Lam QL, Lu L. Role of leptin in immunity. Cell Mol Immunol 2007;4:1-13.

9. Lago R, Gomez R, Lago F, Gomez-Reino J, Gualillo O. Leptin beyond weight regulation-Currebt concept concerning its role in immune function and inflammation. Cell Imun 2008;253:139-45.

10. Franchini G, Ambiden RF, Barry M. Viral disease in hematology. Hematol 2000;20:409.

11. Pichainaron N, Mongkalangon N, Kalayanarooj S, Chaveepojnkamjorn W. Relation between bodysize and severity of dengue hemorrhagic fever among children 
aged $0-14$ years. Southeast Asian J Trop Med Public Health 2006;37:283-8.

12. Sumarmo PS. Masalah demam berdarah dengue di Indonesia Disampaikan pada pelatihan demam berdarah dengue tingkat nasional. Jakarta; 2004.h.23-9.

13. Srikiatkhachorn A, Ajariyakhajorn C, Endy TP. Virusinduced decline in soluble vascular endothelial growth receptor 2 Is associated with plasma leakage in dengue hemorrhagic fever. J Virol 2007;81:1592-600.

14. Soegijanto, S. Demam berdarah dengue. Edisi 2. Surabaya: Airlangga University Press; 2006.

15. Chaturvedi UC, Agarwal EA, Elbishbishi AS, Mustafa. Cytokine cascade in dengue haemorrhagic fever:implication for pathogenesis. FEMS Immunol and Med Microbiol 2000;28:183-8

16. Abbas AK, Lichtman AH. Cellular and Molecular
Immunology. Edisi 5. Philadelphia: Elsevier Saunders; 2007.

17. Ganda IJ. Nilai prognostik tumor necrosis factor alpha demam berdarah dengue pada anak. Sari pediatri 2010;12:254-9.

18. Chakravarti A, Kumaria R. Circulating levels of tumour necrosis factor alpha $\&$ interferon-gama in patients with dengue $\&$ dengue haemorrhagic fever during an outbreak. Indian J Med Res 2006;123:25-30.

19. Gabay C, Dreyer M, Pellegrinelli N, Chicheportche $\mathrm{R}$, Meier C. Leptin directly induces the secretion of interleukin 1 receptor antagonist in human monocytes. J Clin Endocrinol Metab 2001;86:783-91.

20. Fink J, Gu F, Vasudevan SG. Role of T cells, cytokines and antibody in dengue fever and dengue haemorrhagic fever. Rev Med Virol 2006;16:263-75. 